\title{
Work continues despite strikes and corruption
}

"No responsible scientist can waste time doing research if they have a family to feed," declared Thelma Dakubu, a University of Ghana physicist. Ghana's economic collapse dominates the life of scientists as much as anyone else. Just surviving takes increasing time, and the research that does get done is plagued by shortages of supplies and equipment. Yet, despite her comments, Dakubu and other scientists continue their work producing results of international standing.

Money dominates Ghana today. Inflation has been running at $100 \%$ per year for more than two years. But in a period when prices have quadrupled, government salaries have risen only $10 \%$ (most scientists, including university staff, are on government salaries). A typical university lecturer's gross monthly salary is 750 cedis $(£ 130)$. After tax, car loan payments, and subsidised rent, he or she is left with about 300 cedis (about $£ 1.75$ per day) for food, clothing, and other expenses.

Typical prices are: bread, 3 cedis a loaf; a three-pound chicken, 40 cedis; a yam, which will provide basic carbohydrate for a family for two days, 8 cedis; tomatoes, 1 cedi a pound. Prices for other necessities include 7 cedis for a light bulb, 2 cedis for a roll of toilet paper, and 12 cedis for a tube of toothpaste, as the Vice-chancellor of the University of Science and Technology (UST), E. Bamfo Kwakye, admits: "It is not possible for any member of my staff to live on his salary. He must have some other source of income."

Some raise chickens, others have taken to trading or using their cars as taxis. And when they are not earning money, they are out searching for goods. One scientist broke an appointment with me because he had hcard of a place in town selling motor oil. My interview with the head of the Atomic Energy Commission came to an abrupt halt because the Army had arrived to sell cloth. The head, and everyone else at the research centre, queued to buy. Then the interview resumed. The result is clear-less time is left for the lab and classroom. UST is almost deserted in the afternoons. Corruption is also increasing even among scientists. Ghanaians have coined the word 'kalabule' for making a profit through friends.

Some scientists have simply left Ghana. The brain drain has hit the schools, too. More than 4,000 teachers left Ghana between August 1977 and September 1978 and those who remain often attend less than half their classes! The effect can be measured in falling test scores. A survey of "O-level" chemistry exams taken by the top one-third of candidates showed that in $1973,84 \%$ obtained credit or better and $22 \%$ of those excellent or very good. Last year, the figures had fallen to $60 \%$ and $6 \%$ respectively.

Those who stay to do research hit the other half of Ghana's economic crisis - the foreign exchange problem. The military government has diverted foreign exchange to its own uses by granting import licences and letters of credit to government members, friends, and girlfriends. Mercedes Benz cars and luxury goods, as well as expensive military hardware, were imported instead of necessities.

The Council for Scientific and Industrial Research has received no foreign exchange for two years. At UST the bookshop is virtually empty. The most recent copies of journals in the library are months - or even years -old, because subscriptions could not be renewed. Equipment lies unrepaired because spare parts cannot be imported.

At the Atomic Energy Commission's Nuclear Research Establishment-one of the best provided for research units in Ghana-the head of the chemistry department, J. P. H. Brown, said that "sometimes we run out of benzene for months on end". For Dr Sarpong of the UST Faculty of Pharmacy, the worst part is that

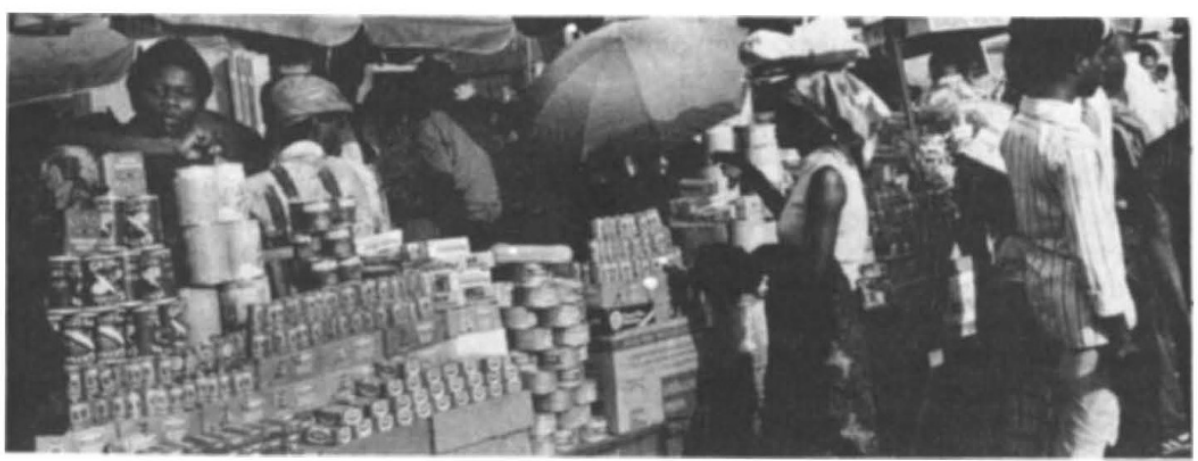

"you sit and wait for months hoping to get chemicals and solvents from outside the country. You are never told you are not going to get them."

But the middle class-which includes scientists--has clearly been the hardest hit. "We could not spend all our time talking about professional concerns when the soldiers were mismanaging things," Ayiku said. So they took to the streets. Strikes by students, teachers, scientists, engineers, lawyers, and doctors during 1977 and 1978 eventually led to General Ignatius Acheampong's resignation.

The University Teachers Association, 13 of whose 15 executive officers are scientists, played a leading role in the strike, despipte threats that they would be sacked, thrown out of their university owned houses and lose their salaries. Students who should have graduated in July had an entire year of studies squeezed into four months, finishing in December. This put pressure on teachers, too. In combination with the strike, many were not able to do any research last year, and have only recently returned to the lab.

Some scientists are still politically active. Dr Ivan Addae-Mensah, a University of Ghana chemist who succeeds in doing both research and political work, explains the position of scientists this way: "In other countries, people say scientists hide in their shells. As an educated person in a developing country, a lot is expected of you. This makes the scientist in a developing country more aware of his social commitments. It is not because we are scientists, but because we are educated that we have a duty."

- Overleaf: Ghana's equipment shortage

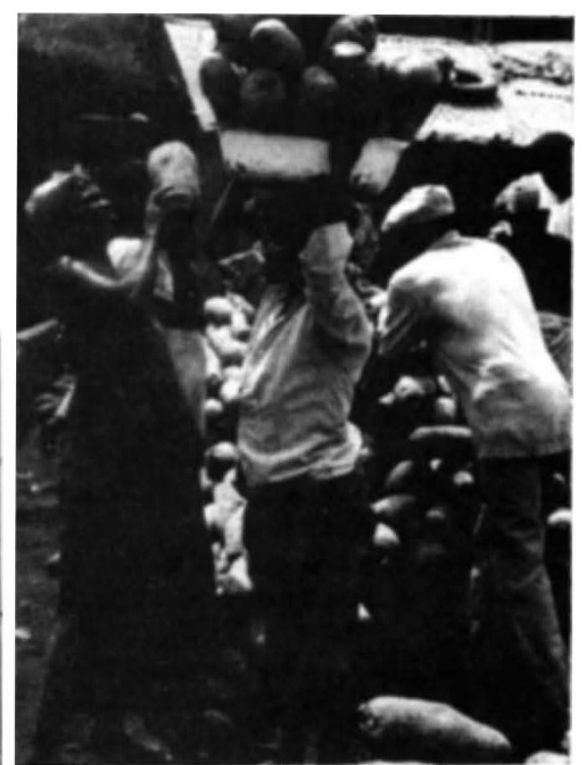

"Money dominates Ghana": consumer goods sell for a fortune and even a yam, the country's staple food, costs 8 cedis, twice the daily minimum wage. 